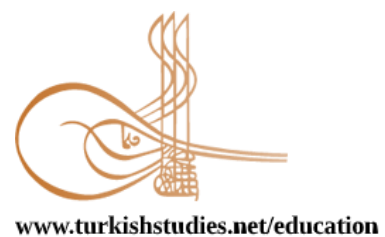

Turkish Studies - Educational Sciences

\title{
İngilizce Öğretmenlerinin Pozitif Psikolojik Sermayeleri ile Öğrencilerin Yabancı Dil Ders Başarıları Arasındaki İlişki*
}

\author{
The Relationship Between English Language Teachers' Positive Psychological Capital And \\ Students' Success in English Courses
}

\author{
Çağan Yıldıran ${ }^{* *}$ - Cavide Demirci ${ }^{* * *}$
}

\begin{abstract}
The affective domain plays an important role in second language learning and teaching. How teachers feel and what personal traits they have is of great importance. Positive psychology is relatively new concept and it presents many research opportunities in second language teaching and learning. The aim of this research is to examine the relation between the positive psychological capital perceptions of English teachers, and their students' succes in English courses, thereby, to discover the effects of this perception on their students'foreign language achievement. On the basis of descriptive scanning model, correlational research design has been used within the research, owing to the fact that there might be relationships among the four main variables. Ninety-five English teachers lecturing in eighth grade of public secondary schools in Adana, and their 2073 eighth grade students were the core participants in the present study. Data were obtained by using three different scales, and lists showing the students' end of the academic year results from English course. Obtained data were analyzed by using descriptive analyses, t-test, correlation, Mann-Whitney U Test, Kruskal-Wallis Test and Spearman Rho correlation analysis. Teachers' positive psychological capital levels have been found "very high". It has been identified that teachers' positive psychological capital level is not a predictor of students' their success in English lessons.
\end{abstract}

Structured Abstract: Introduction: Applications of psychology are not new to SLA; however, new to the area is the introduction of a range of relatively unexamined constructs to the field from the perspective of Positive Psychology (Macintyre, Gregersen, Mercer, 2019, s.262). In the literature, there is a great deal of investigation into the releationship between teachers' positive psychological capital and different variables. These studies are mostly about the teachers' positive psychological capital perception levels (e.g. Tösten, 2015; Ekin,2018;Kaya, Balay \& Demirci, 2014; Yalçın, 2019), leadership in Education (e.g. Savur, 2013;

\footnotetext{
* Bu makale, Eskiş̧ehir Osmangazi Üniversitesi Eğitim Bilimleri Enstitüsü bünyesinde yürütülen, "İngilizce Öğretmenlerinin Pozitif Psikolojik Sermayeleri ile Öğrencilerin İngilizce Dersine Yönelik Tutumları ve Yabancı Dil Kaygıları arasındaki İlişkinin İncelenmesi” adlı doktora tezinden üretilmiştir.

** Öğr. Gör. Dr., Aksaray Üniversitesi, Yabancı Diller Yüksekokulu

Lecturer Dr. University of Aksaray, The School of Foreing Languages

ORCID 0000-0001-6854-3499

osiyildiran@hotmail.com

**** Prof. Dr, Eskişehir Osmangazi Üniversitesi, Eğitim Fakültesi, Eğitim Bilimleri Bölümü

Prof. Dr., Eskisehir Osmangazi University, Faculty of Education, Department of Educational Sciences

ORCID 0000-0003-4789-4286

demircicav@gmail.com

Cite as/ Atıf: Yıldıran, Ç. \& Demirci, C. (2020). İngilizce öğretmenlerinin pozitif psikolojik sermayeleri ile öğrencilerin yabancı dil başarıları arasındaki ilişki. Turkish Studies - Education, 15(4), 3027-3046. https://dx.doi.org/10.47423/TurkishStudies.44554

Received/Geliş: 28 June/Haziran 2020

Accepted/Kabul: 27 August/Ağustos 2020

Copyright $($ INTAC LTD, Turkey

Checked by plagiarism software

Published/Yayın: 30 August/Ağustos 2020

CC BY-NC 4.0
} 
Çetin, Özdemir \& Akpolat, 2017; Keser, 2013; Büyükgöze \& Kavak,2017) teachers' burnt out levels (e.g. Tösten, Arslantaş \& Şahin, 2017), teachers' job satisfaction levels (e.g. Sarıcı, 2015; Çakmak \& Arabacı, 2017), increasing the level of teachers' positive psychological capital (e.g. Kalman, 2017), wellbeing at the workplace (Barut, 2017; Williams, Kern \& Waters, 2015), supportive behaviours for learners' autonomy (e.g.Erbaş,2018).

\section{Method}

On the basis of descriptive scanning model, correlational research design has been used within the research, owing to the fact that there might be relationships among the main variables. Ninety-five English teachers lecturing in eighth grade of public secondary schools in Adana, in 2017-2018 academic year and their 2073 eighth grade students were the core participants in the study. The research data were obtained by using "Teachers' Positive Psychological Capital Scale" by Tosten and Ozkan (1014), the lists showing the students' end of the academic year results from English course and personal information forms. Obtained data were analyzed by using descriptive analyses, t-test, ANOVA, correlation, multiple regression, MannWhitney U Test, Kruskal-Wallis Test and Spearman Rho correlation analysis.

\section{Purpose}

The general aim of this research was to investigate the relationship between English teachers' positive psychological capital perception levels and their students' success in English lessons. In accordance with this purpose, answers to the following questions were sought:

1. What is the level of English teachers' perceptions of positive psychological capital?

2. Does the level of teachers' perceptions differ according to their gender, type of faculty they gradutated from or work experience?

3. Is there a relationship between English teachers' positive psychological capital and their students'success in English lessons?

4. Do the levels of students' sucess in English lessons differ significantly according to their gender?

\section{Results}

According to the study findings, the percieved positive psychological capital levels of teachers are considerably high $(X=4,70)$. This has been found true for 5 subdimensions of the scale; optimism $(4,77)$, self-efficacy $(4,70)$, confidence $(4,42)$, outwardness $(4,34)$, and psychological stability $(4,33)$. As well as the type of faculty they gradutated from $(\mathrm{z}=0.442, \mathrm{p}>0.05)$, Mann Witney $\mathrm{U}$ Test results has shown that in terms of teachers' gender, the levels of positive pysychological perceptions of teachers do not differ significantly $((\mathrm{z}=0.277, \mathrm{p}>0.05)$. When it comes to work experience, Kruskall Wallis H Test has shown that the levels of positive pysychological perceptions of teachers also did not differ significantly $(X 2=1.789, \mathrm{p}>0.05)$. The Spearman's correlation method was applied to determine the relationship between teachers psychological capital levels and their students' success in English lessons. In addition to the results mentioned above, it has been also identified that teachers' positive psychological capital levels is not a predictor of students' success in English. In another words, the Spearman's correlation matrix to determine the relationship between psychological capital of teachers and their students' success in English classes ha sfound that there is no significant relationships $(\mathrm{Rxy}=.0 .070, \mathrm{p}<.0 .05)$. Finally, in terms of students' gender, independent samples $\mathrm{t}$ test has shown that there is a significant difference between English scores of male and female students $(\mathrm{t}=$ 9.628.13, $\mathrm{p}<.05)$. According to this result, female students have higher marks than male students, which means that gender is a predictor of success in English courses.

\section{Conclusion and Suggestions}

According to research results, it has been confirmed that teachers' positive psychological capital level is at "very high" stage in total scale; This finding complies with many preliminary researches as in Tösten (2015), Büyükgöze (2014), Akman (2016), Büyükgöze \& Kavak (2017), Altınkurt, Ertürk \& Yılmaz (2015), Durrah, Alhamoud \& Khan (2016) Eser (2018), Kelekci (2015), Barut (2017), Tösten \& Toprak (2017), Erbaş (2018), and Yalçın (2019) Examining the scores related to subdimensions of scale, it has been seen that they are in "good" level in the dimensions of outwardness and psychological stability, and "very high" in other dimensions of self-efficacy, confidence, and optimism. Furthermore, gender, work experience and the type of faculty teachers gradutated from are not strong 
predictors of teachers' positive pysychological perception levels. In this study, no significant relationships have been detected between teachers' positive psychological capital levels and their students' success in English. According to the results from the study, it can be concluded that teachers' positive psychological capital levels do not predict students' success in English. Finally, it is among the study that there is a significant relationship between gender and success in English courses. Acording to this finding, female students are much more successful in English classes. This finding is parallel with the result that carried out by Bećirović (2017). Considering the research results, to the researchers, it is suggested that they conduct further studies with different participants and scales to investigate the relationship between teachers' positive psychological capital levels and students' success.

Keywords: Educational Sciences, Psychology, Positive Psychology, Positive Psychological Capital, Foreign Language Success

Öz: Duyuşsal alan yabancı dil eğitiminde önemli bir rol oynar. Öğretmenlerin nassl hissettiği ne gibi kişisel özelliklere sahip olduğu hiç şüphesiz büyük öneme haizdir. Pozitif psikoloji nispeten yeni bir kavramdır ve söz konusu dil eğitimi olduğunda, özellikle yeni araştırma alanları sunmaktadır. Bu çalışmada, İngilizce öğretmenlerinin sahip oldukları pozitif psikolojik sermaye algıları ve onların yabancı dil eğitimi sağladıkları ortaokul 8. sınıf öğrencilerinin yabancı dil ders başarıları arasındaki ilişkinin incelenmesi amaçlanmıştır. Bu amaç doğrultusunda, İngilizce öğretmenlerinin pozitif psikolojik sermayeleri ve alt boyutlarına ait alg1 düzeyleri ile öğretmenlerin İngilizce derslerini yürüttükleri ortaokul 8. sınıf öğrencilerinin İngilizce dersi sene sonu başarı notları incelenmiştir. Nicel bir çalışma olan bu araştırmanın çalışma grubunu, Adana ili merkez ilçelerinde bulunan 29 farklı devlet okulunda görev yapmakta olan 95 İngilizce öğretmeni ve bu öğretmenlerin öğrencileri olan 2073 ortaokul 8. sınıf öğrencisi oluşturmaktadır. Araştırma verileri, öğretmenlere uygulanan pozitif psikolojik sermaye ölçeği, öğrencilerin İngilizce dersi yılı sonu ders notu çizelgeleri ile öğretmen ve öğrencilerin demografik bilgi formları aracılığıyla toplanmıştır. Verilerin çözümlenmesinde betimsel analizler, t-testi, korelasyon, Mann Whitney U, Kruskal Wallis ve Spearman Rho korelasyon analizleri kullanılmıştır. İstatistik programı yardımıyla çözümlemeler ile elde edilen araştırma sonuçlarına göre; öğretmenlerin pozitif psikolojik sermaye algı düzeyleri çok yüksek, ancak öğretmenlerin pozitif psikolojik sermaye düzeyleri ile öğrencilerin İngilizce ders başarısı arasında anlamlı bir ilişki bulunmamaktadir.

Anahtar Kelimeler: Eğitim Bilimleri, Psikoloji, Pozitif Psikoloji, Pozitif Psikolojik Sermaye, Yabancı Dil Başarısı

\section{Giriş}

Öğretmenlerin sahip oldukları bilişsel özelliklerinin yanı sıra, duyuşsal özelliklerinin de onların en önemli oyuncu oldukları eğitim öğretim sürecine yansımalarının olması son derece muhtemeldir. Nitekim bu alanda yapılan çalışmalar, öğretmenlerin öz yeterlilik, iyimserlik gibi olumlu psikolojik özelliklerinin, öğrencilerin akademik başarısından, derse katılım, motivasyon, ve performanslarına kadar birç̧ok açıdan etkilediğini ortaya koymaktadır (Chu, Saucier, Hafner, 2010; Williams ve Burden, 1997; Furrer ve Skinner, 2003; Erden, 1998; Wayne ve Youngs, 2003). Gerek öğretim programlarının uygulanmasında gerekse de öğretimin yürütülmesinde iş görenler olarak öğretmenler, eğitim kurumlarının en önemli insan kaynaklarını oluşturmaktadırlar. Kurumların, performans artışı (burada programın iyileştirilmesi) yönünde ölçülebilir, karşılaştırabilir, geliştirilebilir ve yönlendirilebilir olan insan kaynağının ve psikolojik potansiyelinin incelenmesi olarak tanımlanan "psikolojik sermayenin", iş görenlerin (burada öğretmenler) tutum ve davranışlarına yön vermede ne denli etkili olduğu bir dizi araştırmanın konusu olmuştur (Luthans ve Youssef, 2004, s. 143-166; Keleş, 2011, s. 343)

Bir disiplin olarak psikoloji biliminin bulgularının yabancı dil eğitimine uyarlanması yeni bir olgu değildir. Motivasyon, inanç, kimlik, duygu ve öğrenci otonomisi gibi konular, bu alanda yapılan araştırma başlıklarından sadece bazılarını oluşturmaktadır. Ancak yeni olan, pozitif 
psikolojinin gözünden, alanda görece daha az incelenmiş konuların ortaya çıkmasıdır. (MacIntry, Gregersen ve Mercer, 2019, s.1).

Alan yazında öğretmenlerin pozitif psikolojik sermayeleri ile ilgili çeşitli incelemeler yer almaktadır. Bu çalışmalarda genellikle, öğretmenlerin pozitif psikolojik sermaye seviyelerinin incelenmesi (Ör. Tösten, 2015; Ekin, 2018;Kaya, Balay ve Demirci, 2014; Yalçın, 2019), eğitimde liderlik (Ör. Savur, 2013; Çetin, Özdemir ve Akpolat, 2017; Keser, 2013; Büyükgöze ve Kavak,2017) öğretmenlerin tükenmişlik düzeyi (Ör. Tösten, Arslantaş ve Şahin, 2017), öğretmenlerin iş doyumu (Sarıcı, 2015; Çakmak ve Arabac1, 2017), öğretmenlerin pozitif psikolojik sermayelerinin geliştirilmesi (Ör. Kalman, 2017), işyeri iyi oluş (Barut, 2017; Williams, Kern ve Waters, 2015) ve öğretmenlerin öğrenci özerkliğini desteklemeleri (Ör. Erbaş, 2018) konularındaki çalışmalar ile sınırlı kaldığı görülmektedir.

Pozitif psikolojik sermayenin, değişik alanlarda birçok kavramla ilişkisini ortaya koymak üzere çeşitli çalışmalar yürütülmüştür (Yıldız, 2015). Ancak, ulusal ve uluslararası alanyazında, öğretmenlerin pozitif psikolojik sermaye düzeyleri ile öğrencilerin yabancı dil ders başarı arasındaki ilişkinin incelendiği bir çalışmaya rastlanmamıştır. Dolayısıyla, İngilizce öğretmenlerinin pozitif psikolojik sermayelerinin belirtilen kavramla ilişkisinin incelenmesi önemli görülmektedir. $\mathrm{Bu}$ bağlamda, İngilizce öğretmenlerin pozitif psikolojik sermayelerinin incelenmesine ve başka değişkenlerle aralarındaki ilişkilerin belirlenmesine gereksinim duyulduğu söylenebilir. Bu doğrultuda yürütülen çalışmanın alanyazına olumlu katkı yapması beklenmektedir.

\section{Psikoloji, Pozitif Psikoloji ve Pozitif Psikolojik Sermaye}

"Psikoloji, İnsan ve hayvan davranışlarını inceleyen bir bilimdir" (Morgan, 2013,s.5). Diğer bilim dalları ile karşılaştırıldığında kısa bir geçmişe sahip olan psikoloji, dönemin baskın görüşlerinin de etkili olduğu farklı tanımlarla ifade edilmiştir. Örneğin davranışçılığın yaygın olarak kabul gördüğü, hayvan davranışlarının deneysel yöntemler ile incelendiği ve elde edilen sonuçların insanlara genellendiği dönemlerde, "davranış bilimi" ya da "hayvan davranışlarının incelenmesi" şeklinde tanımlamıştır. Ancak günümüzde psikoloji, "davranışı ve davranışa kaynaklık eden süreçleri bilimsel yöntemler ile ele alarak inceleyen çalışma alanı" (Cüceloğlu, 2015,s.34-35) olarak tanımlanmaktadır. Kökleri antik dönemlere dayanmakla birlikte (İnanç ve Yerlikaya,2015,s.1) psikoloji, 19. yüzyıl başlarına kadar felsefe içeresinde daha çok metafizik ağırlıklı konuları ele alırken, 19. yüzyıl sonları ile 20. yüzyıl başlarında daha çok fizyolojiyi konu edinir, bunun sonunda psikofizik biçiminde anılır olmuştur. Ancak 1879 yılında Wilhelm Wundt (1832-1920), Almanya'nın Leipzig şehrinde dünyanın ilk psikoloji laboratuvarını kurmuş ve böylece temellerinin dayandığ 1 felsefe ile yollarını ayıran psikoloji, ayrı bir disiplin olarak kabul görmeye başlamıştır. Burada yürüttüğü çalışmalarda, bilimsel araştırmanın gereği olarak kabul edilen yöntemleri kullanan Wundt, 1881 yılında yeni bilimin ve laboratuvarının resmi yayın organı olarak, Felsefe Çalışmaları (Philosophische Studien) dergisini yayınına başlamıştır. Bu girişimleri ile Wundt, modern psikolojinin kurucusu; ilk laboratuvarın kuruluş tarihi olan 1879 ise, modern psikolojinin kuruluş yılı olarak kabul edilir (Schultz ve Schultz, 2007,s.132-135).

$\mathrm{Bu}$ tarihten itibaren değişik psikolojik akımların etkisine tanıklık edilen alan, zihinsel hastalıkları iyileştirmeyi, normal insanların yaşam kalitesini arttırmayı ve dâhileri araştırmayı kendisine amaç edinmiştir. Ancak toplum ve bireylerin hayatında onulmaz yıkımların görüldüğü II. Dünya Savaşı sonrası, psikoloji, yukarıda bahsedilen amaçlarından birincisinden büyük ölçüde uzaklaşarak yalnızca son iki amacına odaklanmıştır(Linley, 2009). Alan dışı şartların da etkisiyle psikoloji, patoloji odaklı bir anlayışın hakim olduğu bir bilim dalına dönüşmüştür. Seligman ve Csikszentmihalyi (2000,s.5-6), psikoloji biliminin bu dönemini, "II. Dünya savaşı sonrası psikoloji, ağırlıklı bir şekilde bir 'tedavi /iyileştirme' (healing) bilimi haline dönüşmüştür. Psikolojinin hastalıklara odaklandığı bu sürece, hastalık modeli (disease model), psikoloji biliminin bu durumuna da kurbanoloji/mağduroloji (victimology) demek, daha doğru bir tanım olabilir" şeklinde tanımlamayı tercih etmiştir. 
Sosyal bilimlerin cesaret, dürüstlük diğerkâmlık, saygı, zevk, sağlık, sorumluluk ve iyimserlik gibi insani erdemleri, savunmacı stratejiler veya yanılsama olarak değerlendirilerek küçümsemesine, diğer taraftan ise kaygı, bencillik, ihtiras, paranoya, öfke, düzensizlik ve keder gibi, insanın olumsuz motivasyonlarını gerçek olarak nitelendirmesine karşı çıkan (Seligman 1998,s. 1), insan doğası ve potansiyeline ilişkin daha olumlu düşünceler geliştirmeleri yönünde psikologlara çağrıda bulunur. Psikoloji camiasında olumlu bir karşılık bulan bu çağrı, alanda olağanüstü bir yayın artışına yol açmıştır (Schultz ve Schultz, 2007,s.684).

İnsanı daha çok patolojik bir vaka olarak ele almaya eğilimli olan ana akım psikoloji anlayışına bir tür karşı çıkış olan pozitif psikoloji, hayatta neyin yanlış gittiğinden çok "hayatta neyin doğru gittiğinin bilimsel çalışmasıdır" (Peterson, 2006). Pozitif psikoloji, bu anlamda bireylerin olumlu kişilik özeliklerini öne çıkarmayı önceler. Maslow'a (1954, s. 354) göre de, pozitif psikolojinin, deneyimlerimizin "daha karanlık ve daha acımasız" yönleriyle ilgilenmek yerine, sağlıklı oluşun çok daha fazlasını ifade ettiğini kabullenerek, insan deneyimlerini bir bütün olarak, her yönüyle ele almaması için hiçbir sebep yoktur.

"Belirli bir amaç için uygun olan varlık ve kaynakların değeri” (Envick, 2005:s.13) olarak tanımlanan sermaye, geleneksel olarak ekonomi ve finansal anlamda kullanılırken, bugün artık beşeri yeteneklerin ve eğitimin de bir sermaye çeşidi olarak kabul görmesi sonucu, kavramın ifade ettiği kullanım alanı da genişlemiştir. Pozitif psikolojik sermaye, bireyin pozitif psikolojik açıdan gelişme durumlarını ele alır. Psikolojik sermayenin karakteristik özelliklerden farklı olarak bireyin gelişime açık oluşu, onun "kim olduğu" kadar "kim olabileceği" gibi gelişime açık yönleri ile ilgilenir. Kişinin olumlu ve güçlü yönlerinin ortaya çıkarılması ve geliştirilmesi yanında, bunların eğitim ve deneyimler ile değiştirilmesi ve geliştirilmesi mümkün olan bir dizi niteliklerinin bütünüdür (Luthans ve Youssef, 2007,s.10-11;Luthans, Youssef ve Avolio, 2007,s.3; Duffy, 2013,s.98; Peterson, Luthans, Avolio, Walumbwa, ve Zhang, 2011,s.427-430 ).

Bir çatı kavram olan pozitif psikolojik sermaye, bireylerin umut (hope), iyimserlik (optimism), öz-yeterlilik (self-efficacy) ve dayanıklılık (resilience) özellikleri açısından gelişim durumları olarak da tanımlanmaktadır. Öz-yeterlilik, zorlu görevleri başarabilmek için gerekli çaba ve kendine güven; iyimserlik, şu anda ve gelecekte başarmaya dair pozitif beklenti; umut, amaçlara ulaşma yolunda çaba gösterme ve başarmak için farklı seçenekleri deneme; dayanıklılık, engeller ve zorluklara rağmen direnç ve kendi kendini toparlayabilme şeklinde karakterize edilir (Luthans, Youssef, ve Avolio, (2007,s.2; Harms ve Luthans, 2012: 590-591).

TDK (2019), başarı sözcüğünü "başarma işi, muvaffakiyet”, başarmak sözcüğünü ise " bir işi istenilen biçimde bitirmek" olarak tanımlamaktadır. Longman İngilizce Sözlük ise başarıyı, kişinin kendi çabalarını ortaya koyması sonucunda becerdiği önemli şey” olarak açıklamaktadır. Yabancı dilde başarı söz konusu olduğunda ise, elbette ki bireyin yabancı dil ile ne yapmak istediğine bağlı olarak, başarı kavramının açıklaması değişebilir. Örneğin bir yabancı dil sınavında belirli bir puanı hedefleyen kişinin, o puanı alabilecek çalışmayı ortaya koyarak, hedeflediği puanı almasından bir "başarı" olarak söz edilebilir. Ancak, bir yabancı dilde istendik başarı hiç kuşkusuz, hedef dilde dört temel beceride -dinleme, konuşma, okuma ve yazma- yeterliliğe ulaşılması şeklinde açıklanabilir.

$\mathrm{Bu}$ araştırma, İngilizce öğretmenlerinin pozitif psikolojik sermaye algılarını belirlemek, onların algıdüzeyleri ile öğrencilerinin yabancı dil başarısı arasındaki ilişki varmıdır? sorusu bağlamında ortaya koyacağı yanıtlar açısından yapabileceği, her derecedeki katkı bakımından önemlidir.

\section{Araştırmanın Amacı}

$\mathrm{Bu}$ araştırma, İngilizce öğretmenlerinin pozitif psikolojik sermaye alg1 düzeylerini ve öğrencilerin yabancı dil derslerindeki başarılarını tespit etmeyi, bu değişkenlerin birbirleriyle olan ilişkilerini inceleyerek, öğretmenlerin sahip oldukları pozitif psikolojik sermayenin, öğrencilerin 
İngilizce ders başarılarını nasıl etkilediğini ortaya koymayı amaçlamıştır. Bu amacı gerçekleştirmek üzere, araştırmanın genel amacına bağlı olarak oluşturulan aşağıdaki alt problemlerin cevapları aranmıştır.

1. İngilizce öğretmenlerin pozitif psikolojik sermaye algı düzeyleri nasıldır?

2. Pozitif psikolojik sermaye algı düzeyleri cinsiyet, kıdem yılı ve mezun oldukları fakülte türü değişkenlerine göre farklılık göstermekte midir?

3. Öğretmenlerin pozitif psikolojik sermaye algı düzeyleri, öğrencilerinin İngilizce dersi başarı puanlarını anlamlı bir göstergesi midir?

4. Öğrencilerin yabancı dil dersi başarı düzeyleri, cinsiyet değişkenine göre anlamlı bir farkl111k göstermekte midir?

\section{Yöntem}

İngilizce öğretmenlerin pozitif psikolojik sermaye düzeylerinin, öğrencilerin yabancı dil ders başarıları arasında anlamlı bir ilişkinin olup olmadığını ortaya çıkarmayı amaçlayan bu araştırma, nicel araştırma yöntemlerinden ilişkisel tarama modelinde tasarlanmıştır. İlişkisel tarama desenli araştırmalarda amaç, iki veya daha fazla değişkene müdahalede bulunmaksızın, değişkenler arasındaki birlikte değişimi ve değişimin derecesini ortaya çıkarmaktır (Karasar, 2014, s. 109-110.

\section{Evren ve Örneklem}

Bu çalışmanın araştırma grubunu, 2017-2018 eğitim öğretim yılında Adana il merkezinde bulunan devlet ortaokullarında görev yapmakta olan İngilizce öğretmenleri arasından basit tesadüfi örnekleme yöntemi ile seçilen toplam 95 İngilizce öğretmeni ile bu öğretmenlerin öğrencileri olan 2073 öğrenci oluşturmaktadır. Bu örnekleme tekniğinde evreni meydana getiren her bir elemanın örneğe girme şansı söz konusu olabilmektedir ve bu şans eşittir. Bu nedenle, hesaplamalarda her bir elemana verilecek ağırlık da aynı olmaktadır (Arıkan, 2004, s.141).

\section{Veri Toplama Araçları}

Araştırma verilerinin toplanması amacıyla, araştırmacı tarafından geliştirilen öğrenci ve öğretmenler için bilgi formu kullanılmıştır. Bunu yanı sıra öğretmenlere uygulanmak üzere Tösten ve Özgan (2014) tarafindan geliştirilen Pozitif Psikolojik Sermaye Ölçeği (PPSÖ), öğrencilerin yıl içinde yürüttükleri etkinliklerden aldıkları puanların ortalamalarının yer aldığı İngilizce dersi sene sonu başarı notu çizelgeleri kullanılmıştır. Bu işlem için Adana Milli Eğitim Müdürlüğü’nden ve Pozitif Psikolojik Sermaye Ölçeği'nin (PPSÖ), araştırmada kullanılabilmesi için ölçeği geliştiren araştırmacılardan gerekli izinler alınmıştır.

\section{Pozitif Psikolojik Sermaye Ölçeği}

Tösten ve Özgan (2014) tarafindan geliştirilen Pozitif Psikolojik Sermaye Ölçeği (PPSÖ) beşli Likert tipinde hazırlanmıştır. Ölçek "öz yeterlilik", "iyimserlik”, "güven”, "dışa dönüklük", "psikolojik dayanıklılık", ve "umut" olmak üzere toplam altı boyuttan oluşmakta-dır. Ölçekteki maddeler; "1: Tamamen Katılıyorum", "2: Çoğunlukla Katılıyorum", "3: Kararsızım", "4: Az Katılıyorum" ve "5:Hiç Katılmıyorum" şeklinde tanımlanmıştır. Ölçekte ters madde bulunmamaktadır. Araştırmaya katılan katılımcıların araştırma sorularına verdikleri yanıtların aritmetik ortalamaların değerlendirilmesinde "1.00-1.79 = Hiç Katılmıyorum" , "1.80-2.59 = Az Katılıyorum", "2.60 - 3.39 = Kararsızım ", "3.40 - 4.19= Çok Katılıyorum ", " $4.20-5.00=$ Tam Katılıyorum " ölçütleri esas alınmıştır. Bu durumda 4.20 ve üzeri puan alan öğretmenlerin psikolojik sermaye yeterliklerinin "çok iyi”, 3.40-4.19 puan için öğretmenlerin "iyi”, 2.60-3.39 puan alanların "kararsız", 1.80-2.59 puan alan öğretmenlerin "düşük" ve 1.00-1.79 puan alanların "çok düşük "olduğu düşünülmektedir. Pozitif psikolojik sermaye ölçeği toplam 26 maddeden oluşmaktadır. Tösten ve Özgan (2014) tarafından yapılan analizlerde ölçeğin her bir alt boyutu için 
Cronbach Alfa değerleri sırasıyla" öz yeterlilik" için.79, "iyimserlik" için,80, "güven" için,82, "dışa dönüklük" için 79, "psikolojik dayanıklılık" için 76, "umut" için 73 ve toplam.93 olarak hesaplanmıştır. Bu araştırma için yapılan analizde Cronbach Alfa değerleri ise, "öz yeterlilik" alt boyutu için,73, "iyimserlik" alt boyutu için, 87, "güven" alt boyutu için.67, "dışa dönüklük" alt boyutu için 79, "psikolojik dayanıklılık" alt boyutu için 83 , "umut" alt boyutu için 81 ve toplam Cronbach alfa değeri ise 91 olarak bulunmuştur. Ancak, bizim yaptığımız çalışmada ölçeğin 5 alt boyuttan oluştuğu sonucuna ulaşılmıştır. Pozitif psikolojik sermaye ölçeği faktör analizine ait sonuçlar aşağıda sunulmuştur.

Tablo 1: Pozitif Psikolojik Sermaye Ölçeği İçin Faktör Analizi Sonuçları

\begin{tabular}{|c|c|c|c|c|c|}
\hline & Güven & İyimserlik & $\begin{array}{l}\text { Dışa } \\
\text { Dönüklük }\end{array}$ & $\begin{array}{l}\text { Psikolojik } \\
\text { Dayanıklılık/Ol } \\
\text { gunlaşma }\end{array}$ & Öz Yeterlilik \\
\hline PPSÖ22 & 0,811 & & & & \\
\hline PPSÖ24 & 0,782 & & & & \\
\hline PPSÖ23 & 0,778 & & & & \\
\hline PPSÖ26 & 0,756 & & & & \\
\hline PPSÖ19 & 0,674 & & & & \\
\hline PPSÖ25 & 0,578 & & & & \\
\hline PPSÖ21 & 0,547 & & & & \\
\hline PPSÖ20 & 0,523 & & & & \\
\hline PPSÖ13 & & 0,815 & & & \\
\hline PPSÖ11 & & 0,777 & & & \\
\hline PPSÖ10 & & 0,596 & & & \\
\hline PPSÖ12 & & 0,540 & & & \\
\hline PPSÖ7 & & & 0,850 & & \\
\hline PPSÖ8 & & & 0,710 & & \\
\hline PPSÖ6 & & & 0,708 & & \\
\hline PPSÖ5 & & & 0,678 & & \\
\hline PPSÖ9 & & & 0,393 & & \\
\hline PPSÖ14 & & & & 0,720 & \\
\hline PPSÖ18 & & & & 0,697 & \\
\hline PPSÖ17 & & & & 0,673 & \\
\hline PPSÖ16 & & & & 0,526 & \\
\hline PPSÖ15 & & & & 0,499 & \\
\hline PPSÖ1 & & & & & 0,859 \\
\hline PPSÖ3 & & & & & 0,817 \\
\hline PPSÖ4 & & & & & 0,700 \\
\hline \multirow[t]{3}{*}{ PPSÖ2 } & & & & & 0,541 \\
\hline & & & $\begin{array}{l}\mathrm{Cr} \\
(\mathrm{Te}\end{array}$ & $\begin{array}{l}\text { ach's Alpha } \\
\text { m) }\end{array}$ & 0,923 \\
\hline & & & $\begin{array}{l}\mathbf{K e} \\
(\mathbf{K})\end{array}$ & Meyer-Olkin & 0,817 \\
\hline
\end{tabular}

Pozitif Psikolojik Sermaye Ölçeği için uygulanan Faktör Analizi sonucunda KMO değeri $0,817>0,80$ elde edilmiştir. Elde edilen bu değer ölçeğin Faktör Analizi ile modellenebileceğine dair bir ölçüt sunmaktadır. Bu değer neticesinde uygulanan Faktör Analizi sonucunda ölçeğin 5 faktöre ayrıldığı Şekil 1'de görülmektedir. Ölçeğin 5 faktörlü yapısındaki madde faktör yükleri 
0,86 ile 0,40 arasında değişmektedir. Tüm madde faktör yüklerinin sınır değeri olarak kabul edilen 0,3 'ün üzerinde olduğu görülmektedir. Başka bir deyişle ölçekten atılması gereken soru bulunmamaktadır. Elde edilen faktörler sırasıyla Güven ( 8 madde), İyimserlik (4), Dışa Dönüklük (4 madde), Psikolojik Dayanıklılık (5 madde) ve Öz Yeterlilik (4 madde) olarak sinıflandırılıp, adlandırılmıştır. Ek olarak 5 faktörlü yapısıyla açıklanan ölçeğin tamamına yönelik Cronbach's Alfa katsayısının $0,923<0,80$ bulunması ölçeğin kullanılabilirliğini desteklemektedir (Tablo 1.). Ölçek bu çalışmada 5 faktörlü yapısıyla kullanılmıştır.

\section{Verilerin Analizi}

Araştırma sonucu elde edilen veriler incelenmiştir. Ölçek maddelerini eksik, bütün maddelere aynı cevapları işaretleyen veya boş bırakan katılımcıların formları değerlendirme dışı tutulmuştur. Sonuç olarak, yapılan eksik değer ve aykırı değer analizleri sonucunda veri setinde 95 öğretmen ve 2073 öğrencinin verileri değerlendirmeye alınmıştır. Değerlendirmeye alınan veriler kodlarak bilgisayara yüklenmiş ve SPSS 22 istatistik paket programı yardımıyla analize tabi tutulmuştur. Bu bağlamda araştırma kapsamında ölçek uygulamasından elde edilen veriler, frekans ve yüzde dağılımı, standart sapma, ba $\neg$ ğımsız $\mathrm{t}$ testi, ANOVA, korelasyon, çoklu regresyon analizi, Mann Whitney U, Kruskal Wallis ve Spearman Rho korelasyon analizleri yoluyla çözümlenmiştir.

\section{Bulgular ve Yorum}

İngilizce öğretmenlerinin psikolojik sermaye algısı düzeylerini belirlemek ölçek maddelerine verdikleri cevapların analizleri sonucu elde edilen bulgulara ilişkin frekans dağılım değerleri tablo 2'de sunulmuştur. 
Tablo 2: İngilizce Öğretmenlerin Psikolojik Sermaye Algısı Ölçeği Frekans Analizleri

Madde

$\begin{array}{lllllllllllllllll}\text { Yaptığım } & \text { işlerin } & \text { tüm } & \text { aşamalarında } & 0 & 0.0 & 0 & 0.0 & 0 & 0.0 & 32 & 33.7 & 63 & 66.3 & 4.66 & 0.48\end{array}$ kendimden eminimdir.

$\begin{array}{llllllllllll}0 & 0.0 & 0 & 0.0 & 0 & 0.0 & 20 & 21.1 & 75 & 78.9 & 4.79 & 0.41\end{array}$

Kendime güvenir im.

$\begin{array}{llllllllllll}0 & 0.0 & 0 & 0.0 & 1 & 1.1 & 22 & 23.2 & 72 & 75.8 & 4.75 & 0.46\end{array}$

Başarı için yapmam gerekeni biliyorum.

$\begin{array}{llllllllllll}0 & 0.0 & 0 & 0.0 & 5 & 5.3 & 28 & 29.5 & 62 & 65.3 & 4.60 & 0.59\end{array}$

alacağımı bilirim.

Hayat dolu bir insanımdır.

Enerji doluyum.

$\begin{array}{llllllllllll}0 & 0.0 & 0 & 0.0 & 11 & 11.6 & 49 & 51.6 & 35 & 36.8 & 4.25 & 0.65\end{array}$

Hayat güzeldir.

$\begin{array}{llllllllllll}0 & 0.0 & 0 & 0.0 & 15 & 15.8 & 41 & 43.2 & 39 & 41.1 & 4.25 & 0.71\end{array}$

Güler yüzlüyüm.

$\begin{array}{llllllllllll}0 & 0.0 & 0 & 0.0 & 8 & 8.4 & 39 & 41.1 & 48 & 50.5 & 4.42 & 0.65\end{array}$

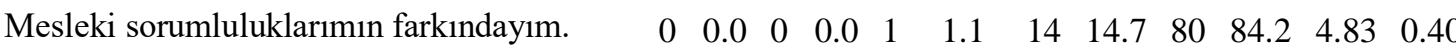

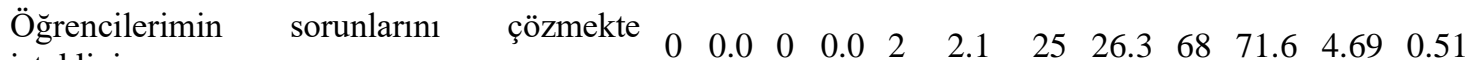
istekliyim.

Mesleğimde güvenilir birisi olduğumu $\begin{array}{lllllllllllll}0 & 0.0 & 0 & 0.0 & 0 & 0.0 & 22 & 23.2 & 73 & 76.8 & 4.77 & 0.42\end{array}$ söylerler.

Yaptığım her iş için hesap verebilirim. $\quad \begin{array}{lllllllllllll}0 & 0 & 0.0 & 0 & 0.0 & 1 & 1.1 & 17 & 17.9 & 77 & 81.1 & 4.80 & 0.43\end{array}$

Mesleğimle ilgili konularda istenirse bir $\begin{array}{rlllllllllllll}0 & 0.0 & 3 & 3.2 & 13 & 13.7 & 37 & 38.9 & 42 & 44.2 & 4.24 & 0.81\end{array}$ grubu bilgilendiririm.

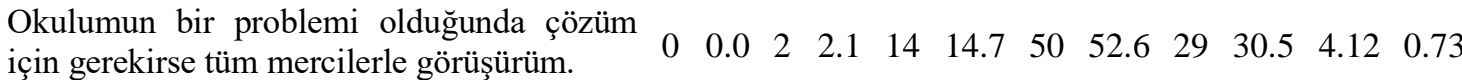

$\begin{array}{llllllllllll}0 & 0.0 & 1 & 1.1 & 11 & 11.6 & 50 & 52.6 & 33 & 34.7 & 4.21 & 0.68\end{array}$

Okulum için yeni fikirler geliştiririm.

Mesleki konularda kurumumu temsil $\begin{array}{lllllllllllll}0 & 0.0 & 2 & 2.1 & 12 & 12.6 & 28 & 29.5 & 53 & 55.8 & 4.39 & 0.79\end{array}$ edebilirim.

Çalışma hayatımda şeffaf olmayı tercih $\begin{array}{lllllllllllll}0 & 0.0 & 0 & 0.0 & 6 & 6.3 & 18 & 18.9 & 71 & 74.7 & 4.68 & 0.59\end{array}$ ederim.

Öğrencilerimin eğitimi için çevredeki

olumsuzluklarla mücadele ederim.

$\begin{array}{llllllllllll}0 & 0.0 & 0 & 0.0 & 7 & 7.4 & 35 & 36.8 & 53 & 55.8 & 4.48 & 0.63\end{array}$

Kurumumdaki bir sorun için yapıcı katkılar $\begin{array}{lllllllllllll}0 & 0.0 & 0 & 0.0 & 3 & 3.2 & 40 & 42.1 & 52 & 54.7 & 4.52 & 0.56\end{array}$ sağlarım.

$\begin{array}{llllllllllllllll}\text { Beklenmedik } & \text { sorunlara } & & \text { çözmler } & 0 & 0.0 & 0 & 0.0 & 9 & 9.5 & 44 & 46.3 & 42 & 44.2 & 4.35 & 0.65\end{array}$ geliştirebilirim.

Zorluklar mücadele azmimi arttırır.

$\begin{array}{llllllllllll}0 & 0.0 & 1 & 1.1 & 13 & 13.7 & 45 & 47.4 & 36 & 37.9 & 4.22 & 0.72\end{array}$

Güçlükler karşısında mücadele ederim.

$\begin{array}{llllllllllll}0 & 0.0 & 0 & 0.0 & 10 & 10.5 & 42 & 44.2 & 43 & 45.3 & 4.35 & 0.66\end{array}$

Yaşadığım problemler beni olgunlaştırır.

$\begin{array}{llllllllllll}0 & 0.0 & 0 & 0.0 & 4 & 4.2 & 35 & 36.8 & 56 & 58.9 & 4.55 & 0.58\end{array}$

Mesleğimi icra ederken aynı anda birçok işin üstesinden gelirim.

$\begin{array}{llllllllllll}0 & 0.0 & 0 & 0.0 & 7 & 7.4 & 44 & 46.3 & 44 & 46.3 & 4.39 & 0.62\end{array}$

Öğretmenlik hayatımda karşılaşabileceğim problemlerle bir şekilde baș edebilirim.

$\begin{array}{llllllllllll}0 & 0.0 & 1 & 1.1 & 3 & 3.2 & 35 & 36.8 & 56 & 58.9 & 4.54 & 0.62\end{array}$

Tablo 2 incelendiğinde, en yüksek katılmanın olduğu ifade "Mesleki sorumluluklarımın farkındayım." maddesi olduğu görülmektedir. Ölçeğin bu maddesine öğretmenlerin verdikleri 
yanıtların frekans dağılımları şu şekildedir; \%1.1 kararsızım $(\mathrm{n}=1), \% 14.7$ çoğunlukla katılıyorum $(\mathrm{n}=14)$, \%84.2 tamamen katıliyorum $(\mathrm{n}=80)$. Madde ortalaması incelendiğinde $(4.83 \pm 0.4)$ öğretmenlerin soruya verdikleri yanıtların ortalamasının tamamen katılıyorum cevabına yakın olduğu görülmektedir.

En yüksek katılmanın gerçekleştiği ikinci madde ise, "Yaptığım işlerin tüm aşamalarında kendimden eminimdir." olmuştur. Ölçeğin bu maddesine öğretmenlerin verdikleri yanıtların frekans dağılımları şu şekildedir; \%33.7 çoğunlukla katılıyorum $(\mathrm{n}=32)$, \%66.3 tamamen katılıyorum $(\mathrm{n}=63)$. Madde ortalaması incelendiğinde (4.66 \pm 0.48$)$ öğretmenlerin soruya verdikleri yanıtların ortalamasının tamamen katılıyorum cevabına yakın olduğu görülür.

En yüksek katılmanın gerçekleştiği üçüncü madde ise, "Kendime güvenirim." ifadesi olmuştur. Ölçeğin bu maddesine öğretmenlerin verdikleri yanıtların frekans dağılımları şu şekildedir; \%21,1 çoğunlukla katıliyorum $(n=20)$, \%78.9 tamamen katılıyorum $(n=75)$. Madde ortalaması incelendiğinde $(4.79 \pm 0.41)$ öğretmenlerin soruya verdikleri yanıtların ortalamasının tamamen katılıyorum cevabına yakın olduğu görülmektedir.

Öğretmenlerin yanıtları incelendiğinde en az katılmanın "Okulumun bir problemi olduğunda çözüm için gerekirse tüm mercilerle görüşürüm.” ifadesinde olduğu görülmektedir. Ölçeğin bu maddesine öğretmenlerin verdikleri yanıtların frekans dağılımları şu şekildedir; $\% 2.1 \mathrm{az}$ katılıyorum $(n=2), \% 14.7$ kararsızım $(n=14), \% 52.6$ çoğunlukla katılıyorum $(n=50), \% 30.5$ tamamen katılıyorum $(n=29)$. Madde ortalaması incelendiğinde $(4.12 \pm 0.73)$ öğretmenlerin soruya verdikleri yanıtların ortalamasının çoğunlukla katılıyorum cevabına yakın olduğu görülmektedir.

Öğretmen yanıtları incelendiğinde en düşük katılmanın gerçekleştiği ikinci maddenin ise "Zorluklar mücadele, azmimi arttırır." ifadesinde olduğu görülmektedir. Ö̈lçeğin bu maddesine öğretmenlerin verdikleri yanıtların frekans dağılımları şu şekildedir; \%1.1 az katılıyorum $(n=1)$, \%13.7 kararsızım $(\mathrm{n}=13), \% 47.4$ çoğunlukla katılıyorum $(\mathrm{n}=45), \% 37.9$ tamamen katılıyorum $(n=36)$. Madde ortalaması incelendiğinde $(4.22 \pm 0.72)$ öğretmenlerin soruya verdikleri yanıtların ortalamasının çoğunlukla katılıyorum cevabına yakın olduğu görülmektedir.

En düşük katılmanın olduğu üçüncü madde ise, "Okulum için yeni fikirler geliştiririm.” ifadesinde gerçekleşmiştir. Ölçeğin bu maddesine öğretmenlerin verdikleri yanıtların frekans dağılımları şu şekildedir;\%1.1 az katılıyorum $(\mathrm{n}=1), \% 11.6$ kararsızım $(\mathrm{n}=11), \% 52.6$ çoğunlukla katılıyorum $(\mathrm{n}=50), \% 34.7$ tamamen katıliyorum $(\mathrm{n}=33)$. Madde ortalaması incelendiğinde $(4.21 \pm 0.68)$ öğretmenlerin soruya verdikleri yanıtların ortalamasının çoğunlukla katılıyorum cevabına yakın olduğu görülmektedir.

İngilizce öğretmenlerinin, cinsiyet k1dem y1lı ve mezun oldukları fakülte türüne göre, pozitif psikolojik sermaye algı düzeylerine ilişkin bulgular aşağıda sunulmuştur.

Cinsiyet değişkenine göre; 
Tablo 3: Cinsiyete Göre Pozitif Psikolojik Sermaye Algıs1 Mann Whitney U Testi İstatistikleri

\begin{tabular}{|c|c|c|c|c|c|c|c|}
\hline Değişken & Cinsiyet & $\mathbf{N}$ & $\bar{X}$ & S.S & $\overline{\boldsymbol{r}}$ & $\mathbf{Z}$ & $\mathbf{P}$ \\
\hline \multirow{2}{*}{ Öz Güven } & Erkek & 78 & 4.428 & 0.461 & 48.205 & \multirow{2}{*}{-0.156} & \multirow{2}{*}{0.876} \\
\hline & Kadın & 17 & 4.404 & 0.493 & 47.059 & & \\
\hline \multirow{2}{*}{ İyimserlik } & Erkek & 78 & 4.792 & 0.333 & 48.660 & \multirow{2}{*}{-0.567} & \multirow{2}{*}{0.571} \\
\hline & Kadın & 17 & 4.691 & 0.438 & 44.971 & & \\
\hline \multirow{2}{*}{ Dışa Dönüklük } & Erkek & 78 & 4.379 & 0.479 & 49.564 & \multirow{2}{*}{-1.197} & \multirow{2}{*}{0.231} \\
\hline & Kadın & 17 & 4.165 & 0.637 & 40.824 & & \\
\hline Psikolojik & Erkek & 78 & 4.331 & 0.522 & 47.353 & \multirow{2}{*}{-0.495} & \multirow{2}{*}{0.621} \\
\hline Dayanıklılık/Olgunlaşma & Kadın & 17 & 4.318 & 0.686 & 50.971 & & \\
\hline \multirow{2}{*}{ Öz Yeterlilik } & Erkek & 78 & 4.692 & 0.337 & 47.013 & \multirow{2}{*}{-0.785} & \multirow{2}{*}{0.432} \\
\hline & Kadın & 17 & 4.735 & 0.348 & 52.529 & & \\
\hline \multirow{2}{*}{ Psikolojik Sermaye } & Erkek & 78 & 4.524 & 0.323 & 48.365 & \multirow{2}{*}{-0.277} & \multirow{2}{*}{0.782} \\
\hline & Kadın & 17 & 4.463 & 0.444 & 46.324 & & \\
\hline
\end{tabular}

Öz güven, iyimserlik, dışa dönüklük, psikolojik dayanıklılık ve öz yeterlilik alt ölçekleri ile toplam pozitif psikolojik sermaye algısı bakımından kadın ve erkek öğretmenler arasında, \%95 güven düzeyinde istatistiksel olarak anlamlı bir fark saptanmamıştır. ( $\mathrm{z}=-0.156, \mathrm{p}>0.05)$.

Kıdem yılına göre; 
Tablo 2: Mesleki Kıdem Yılına Göre Pozitif Psikolojik Sermaye Algısı Kruskall Wallis H Testi İstatistikleri

\begin{tabular}{|c|c|c|c|c|c|c|c|}
\hline Değişken & Mesleki Kıdem Yılı & $\mathbf{N}$ & $\bar{X}$ & S.S & $\overline{\boldsymbol{r}}$ & $X^{2}$ & $\mathbf{P}$ \\
\hline \multirow{5}{*}{ Güven } & 1-5 Y1l Aras1 & 12 & 4.302 & 0.441 & 39.375 & \multirow{5}{*}{2.367} & \multirow{5}{*}{0.669} \\
\hline & 6-10 Y1l Aras1 & 11 & 4.420 & 0.384 & 46.773 & & \\
\hline & 11-15 Y1l Arası & 36 & 4.382 & 0.537 & 46.750 & & \\
\hline & 16-20 Y1l Arası & 26 & 4.486 & 0.450 & 51.538 & & \\
\hline & 20 Yildan Daha Fazla & 10 & 4.563 & 0.324 & 55.000 & & \\
\hline \multirow{5}{*}{ İyimserlik } & 1-5 Y1l Aras1 & 12 & 4.625 & 0.377 & 35.083 & \multirow{5}{*}{4.724} & \multirow{5}{*}{0.317} \\
\hline & 6-10 Y1l Aras1 & 11 & 4.773 & 0.378 & 46.500 & & \\
\hline & 11-15 Y1l Arası & 36 & 4.750 & 0.414 & 49.375 & & \\
\hline & 16-20 Y1l Arası & 26 & 4.817 & 0.288 & 49.654 & & \\
\hline & 20 Yildan Daha Fazla & 10 & 4.925 & 0.121 & 55.900 & & \\
\hline \multirow{5}{*}{ Dışa Dönüklük } & 1-5 Y1l Arasi & 12 & 4.333 & 0.492 & 48.750 & \multirow{5}{*}{2.056} & \multirow{5}{*}{0.725} \\
\hline & 6-10 Y1l Arası & 11 & 4.436 & 0.344 & 51.409 & & \\
\hline & 11-15 Y1l Arası & 36 & 4.283 & 0.619 & 46.167 & & \\
\hline & 16-20 Y1l Arası & 26 & 4.308 & 0.457 & 44.865 & & \\
\hline & 20 Yildan Daha Fazla & 10 & 4.540 & 0.433 & 58.100 & & \\
\hline \multirow{5}{*}{$\begin{array}{l}\text { Psikolojik } \\
\text { Dayanıklılık/ } \\
\text { Olgunlaşma }\end{array}$} & 1-5 Y1l Arası & 12 & 4.467 & 0.345 & 52.958 & \multirow{5}{*}{4.477} & \multirow{5}{*}{0.345} \\
\hline & 6-10 Y11 Arası & 11 & 4.509 & 0.404 & 56.318 & & \\
\hline & 11-15 Y11 Arası & 36 & 4.206 & 0.649 & 43.278 & & \\
\hline & 16-20 Y1l Arası & 26 & 4.269 & 0.563 & 44.558 & & \\
\hline & 20 Yildan Daha Fazla & 10 & 4.560 & 0.350 & 58.850 & & \\
\hline \multirow{5}{*}{ Öz Yeterlilik } & 1-5 Y1l Arasi & 12 & 4.667 & 0.308 & 42.833 & \multirow{5}{*}{0.871} & \multirow{5}{*}{0.929} \\
\hline & 6-10 Y1l Aras1 & 11 & 4.795 & 0.101 & 49.591 & & \\
\hline & 11-15 Y1l Arası & 36 & 4.715 & 0.334 & 49.653 & & \\
\hline & 16-20 Y1l Arası & 26 & 4.663 & 0.393 & 46.327 & & \\
\hline & 20 Yildan Daha Fazla & 10 & 4.675 & 0.426 & 50.850 & & \\
\hline \multirow{5}{*}{$\begin{array}{l}\text { Psikolojik } \\
\text { Sermaye Algısı }\end{array}$} & 1-5 Y1l Arasi & 12 & 4.479 & 0.305 & 43.708 & \multirow{5}{*}{1.789} & \multirow{5}{*}{0.774} \\
\hline & 6-10 Y1l Aras1 & 11 & 4.587 & 0.208 & 51.909 & & \\
\hline & 11-15 Y1l Arası & 36 & 4.467 & 0.418 & 46.750 & & \\
\hline & 16-20 Y1l Arası & 26 & 4.509 & 0.333 & 46.500 & & \\
\hline & 20 Yildan Daha Fazla & 10 & 4.653 & 0.250 & 57.250 & & \\
\hline
\end{tabular}

Öz güven, iyimserlik, dışa dönüklük, psikolojik dayanıklılık ve öz yeterlilik alt ölçekleri ile toplam pozitif psikolojik sermaye algısı bakımından mesleki kıdem yılına göre, öğretmenler arasında, \%95 güven düzeyinde istatistiksel olarak anlamlı bir fark saptanmamıştır $\left(\mathrm{X}^{\wedge} 2=1.789\right.$, $\mathrm{p}>0.05)$. 
Fakülte türüne göre;

Tablo 4: Mezun Olunan Fakülte Türüne Göre Pozitif Psikolojik Sermaye Algısı Mann Whitney U Testi İstatistikleri

\begin{tabular}{|c|c|c|c|c|c|c|c|}
\hline Değişken & Fakülte & $\mathbf{N}$ & $\bar{X}$ & S.S & $\overline{\boldsymbol{r}}$ & $\mathbf{Z}$ & $\mathbf{P}$ \\
\hline \multirow{2}{*}{ Öz Güven } & Eğitim Fakültesi & 76 & 4.424 & 0.480 & 48.375 & \multirow{2}{*}{-0.267} & \multirow{2}{*}{0.790} \\
\hline & Fen Edebiyat Fakültesi & 19 & 4.421 & 0.407 & 46.500 & & \\
\hline \multirow{2}{*}{ İyimserlik } & Eğitim Fakültesi & 76 & 4.750 & 0.367 & 46.211 & \multirow{2}{*}{-1.435} & \multirow{2}{*}{0.151} \\
\hline & Fen Edebiyat Fakültesi & 19 & 4.868 & 0.281 & 55.158 & & \\
\hline \multirow{2}{*}{ D1şa Dönüklük } & Eğitim Fakültesi & 76 & 4.324 & 0.489 & 46.757 & \multirow{2}{*}{-0.888} & \multirow{2}{*}{0.374} \\
\hline & Fen Edebiyat Fakültesi & 19 & 4.411 & 0.613 & 52.974 & & \\
\hline Psikolojik & Eğitim Fakültesi & 76 & 4.332 & 0.583 & 48.809 & \multirow{2}{*}{-0.577} & \multirow{2}{*}{0.564} \\
\hline Dayanıklılık/Olgunlaşma & Fen Edebiyat Fakültesi & 19 & 4.316 & 0.407 & 44.763 & & \\
\hline \multirow{2}{*}{ Öz Yeterlilik } & Eğitim Fakültesi & 76 & 4.697 & 0.342 & 47.789 & \multirow{2}{*}{-0.156} & \multirow{2}{*}{0.876} \\
\hline & Fen Edebiyat Fakültesi & 19 & 4.711 & 0.326 & 48.842 & & \\
\hline \multirow{2}{*}{ Psikololjik Sermaye } & Eğitim Fakültesi & 76 & 4.505 & 0.350 & 47.375 & \multirow{2}{*}{-0.442} & \multirow{2}{*}{0.658} \\
\hline & Fen Edebiyat Fakültesi & 19 & 4.545 & 0.336 & 50.500 & & \\
\hline
\end{tabular}

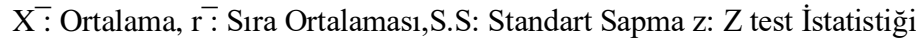

Öz güven, iyimserlik, dışa dönüklük, psikolojik dayanıklılık ve öz yeterlilik alt ölçekleri ile toplam pozitif psikolojik sermaye algısı bakımından, mezun oldukları fakülte türüne göre öğretmenler arasında, \%95 güven düzeyinde istatistiksel olarak anlamlı bir fark saptanmamıştır $(\mathrm{z}=-0.442, \mathrm{p}>0.05)$.

İngilizce öğretmenlerinin pozitif psikolojik sermaye algıları puan ortalaması ve alt boyutlarının, ortaokul 8. sınıf öğrencilerinin İngilizce dersi başarı puanlarını yordayıcılığına ilişkin bulgular aşağıdaki gibidir.

Tablo 5: Öğretmen Pozitif Psikolojik Sermaye Ölçeği İle Öğrenci İngilizce Dersi Ortalama Başarı Puanı Spearman Korelasyon Matrisi

\begin{tabular}{|c|c|c|c|c|c|c|c|c|}
\hline Değişken & İstatistik & 1 & 2 & 3 & 4 & 5 & 6 & 7 \\
\hline \multirow{2}{*}{ 1.Güven } & $\mathrm{R}_{\mathrm{xy}}$ & 1.000 & .418 & .570 & .589 & .480 & .836 & .011 \\
\hline & $\mathrm{P}$ & & .000 & .000 & .000 & .000 & .000 & .915 \\
\hline \multirow{2}{*}{ 2.İyimserlik } & $\mathrm{R}_{\mathrm{xy}}$ & & 1.000 & .347 & .489 & .398 & .624 & -.047 \\
\hline & $\mathrm{p}$ & & & .001 & .000 & .000 & .000 & .651 \\
\hline \multirow{2}{*}{ 3.D1şa Dönüklük } & $\mathrm{R}_{\mathrm{xy}}$ & & & 1.000 & .432 & .445 & .780 & .070 \\
\hline & $\mathrm{p}$ & & & & .000 & .000 & .000 & .497 \\
\hline \multirow{2}{*}{$\begin{array}{l}\text { 4.Psikolojik } \\
\text { Dayanıklılık/Olgunlașma }\end{array}$} & $\mathrm{R}_{\mathrm{xy}}$ & & & & 1.000 & .537 & .801 & .037 \\
\hline & $\mathrm{p}$ & & & & & .000 & .000 & .723 \\
\hline \multirow{2}{*}{ 5.Öz Yeterlilik } & $\mathrm{R}_{\mathrm{xy}}$ & & & & & 1.000 & .699 & .144 \\
\hline & $\mathrm{p}$ & & & & & & .000 & .165 \\
\hline \multirow{2}{*}{ 6.Psikololjik Sermaye } & $\mathrm{R}_{\mathrm{xy}}$ & & & & & & 1.000 & .070 \\
\hline & $\mathrm{p}$ & & & & & & & .503 \\
\hline \multirow{2}{*}{ 7.Başarı notu } & $R_{x y}$ & & & & & & & 1.000 \\
\hline & $\mathrm{p}$ & & & & & & & \\
\hline
\end{tabular}

Rxy: X ve Y gibi iki değişken arasındaki korelasyon katsayısı 
Tabloda görüldüğg̈ üzere öğrencilerin ortalama İngilizce başarı notu ile öğretmenleri öz güven ( $R x y=0.011, p>0.05)$, iyimserlik $(R x y=-0.047, p>0.05)$, dişa dönüklük $(R x y=0.070, p>0.05)$, psikolojik dayanıklılık $(\mathrm{Rxy}=0.037, \mathrm{p}>0.05)$, özyeterlilik $(\mathrm{Rxy}=0.144, \mathrm{p}>0.05)$ düzeyleri ve toplam pozitif psikolojik sermaye düzeyi ( $\mathrm{Rxy}=0.070, \mathrm{p}>0.05)$ arasındaki korelasyon katsayıları istatistiksel olarak anlamsızdır. Daha açık bir ifade ile öğretmenlerin güven, iyimserlik, dışa dönüklük, psikolojik dayanıklılık, öz yeterlilik ve toplam pozitif psikolojik sermaye algıları ile eğitim verdikleri öğrencilerin ortalama İngilizce başarı notları arasında bir ilişki saptanamamıştır.

Öğrencilerin yabancı dil dersi başarı düzeylerine ilişkin bulgular aşağıda sunulmuştur.

Tablo 6: İngilizce Başarı Puanı Ortalama ve Standart Sapma Düzeyine İlişkin İstatistikler

\begin{tabular}{llcccc}
\hline Değişken & N & Minimum & Maksimum & $\overline{\boldsymbol{X}}$ & S.S \\
\hline Başarı Notu & 2073 & 14.50 & 100.00 & 74.56 & 18.68 \\
\hline \multicolumn{7}{c}{ X :ortalama, S.S: Standart Sapma } \\
\hline
\end{tabular}

İngilizce başarı puanı minumum 14.50, maksimum 100, ortalama 74.56 ve 18.68 standart sapma değerine sahiptir. 0- 24 arası çok düşük, 25-44 arası düşük, 45-54 arası orta, 55-69 arası orta üst, 70-84 arası yüksek ve 85-100 aras1 ise çok yüksek olarak değerlendirilmiştir. Buna göre öğrencilerin İngilizce dersi başarı puanları ortalamasının yüksek olduğunu söylenebilir.

İngilizce başarı puanı normal dağılım test istatistikleri tablo 7'de sunulmuştur.

Tablo 7: İngilizce Başarı Puanı Normal Dağılım Test İstatistikleri

\begin{tabular}{lllllllllll}
\hline \multirow{2}{*}{ Değişken } & \multicolumn{2}{c}{ Kolmogorov-Smirnov } & \multicolumn{2}{c}{ Shapiro-Wilk } & \multicolumn{2}{c}{ S } & \multicolumn{3}{c}{ K } & \\
\cline { 2 - 10 } & ist. & s.d & P & ist. & s.d & P & İst & s.d & ist. & s.d \\
\hline \multirow{2}{*}{ Başarı Notu } & .099 & 2073 & .000 & .941 & 2073 & .000 & -.553 & .054 & -.636 & .107 \\
\hline
\end{tabular}

S: Çarpıklık, K:Basıklık, ist.: İstatistik, s.d:Serbestlik Derecesi, s.h: standart Hata

Tabloda görüldüğü üzere başarı puanı değişkeni tam olarak normal dağılmamakla beraber aşırı bir çarpıklığa sahip olmadığından normal dağılımın sağlandığını düşünülmesi hata olmayacaktır.

Öğrencilerinin İngilizce dersi başarı düzeyinin, cinsiyet değişkenine göre farkına ilişkin bulgular aşağıdaki gibidir.

Tablo 8: Cinsiyete Göre Öğrencilerin İngilizce Dersi Başarı Notları Bakımından Farklarını Sınayan Bağımsız Örneklem T-testi İstatistikleri

\begin{tabular}{llllllll}
\hline Değişken & Cinsiyet & $\mathbf{N}$ & $\overline{\boldsymbol{X}}$ & $\mathbf{S . S}$ & $\mathbf{T}$ & $\mathbf{P}$ & $\mathbf{D}$ \\
\hline İngilizce Dersi Başarı Kadın & 1136 & 78.068 & 17.254 & & \\
Puanı & Erkek & 937 & 70.302 & 19.449 & $9.628^{*}$ & 0.000 & 0.423 \\
\hline \multirow{2}{*}{$\%$ 95 güzev düzeyinde anlamlı farklılığı simgeler,X } & \\
\hline
\end{tabular}

Tabloda görüldüğü üzere İngilizce dersi başarı puanı bakımından kız (78.068 \pm 17.254$)$ ve erkek (70.32 \pm 19.449$)$ ögrenciler arasında $\% 95$ güven düzeyinde istatistiksel olarak anlamlı bir fark saptanmıştır. $(\mathrm{t}=9.628, \mathrm{p}<0.05)$. Ortalama değerler incelendiğinde farkın kadın öğrenciler lehine olduğu görülmektedir. Daha açık bir ifade ile kız öğrencilerin İngilizce dersi başarı puanları erkek öğrencilerden manidar bir şekilde yüksektir. Etki büyüklüğü ortaya yakındır. $(0.2<|\mathrm{d}|<0.5)$. 


\section{Sonuç ve Tartışma}

$\mathrm{Bu}$ araştırmanın amacı, İngilizce öğretmenlerin pozitif psikolojik sermaye algı düzeyleri ile öğrencilerin yabancı dil dersi başarı düzeylerini belirlemek ve bu değişkenler arasında anlamlı bir ilişki olup olmadığını saptamaktır. Araştırma sonucunda ulaşılan sonuçlara aşağıda yer verilmiştir.

Öğretmenlerin psikolojik sermaye alg1 düzeylerine incelendiğinde, pozitif psikolojik sermaye algılarının yüksek olduğu saptanmıştır. Alan yazına bakıldığında, yapılan birçok çalışmada bu sonucu destekler nitelikte bulgulara ulaşıldığı görülmüştür. Tösten (2015), Büyükgöze (2014), Akman (2016), Büyükgöze ve Kavak (2017), Altınkurt, Ertürk ve Y1lmaz (2015), Eser (2018), Kelekci (2015), Barut (2017), Tösten ve Toprak (2017), Erbaş (2018) ve Yalçın (2019) tarafindan yapılan çalışmalarda, öğretmenlerin pozitif psikolojik sermaye düzeyi algıları oldukça yüksek çıkmıştır. Bu sonuçlar, Oruç (2015) tarafından akademisyenler arasında yürütülen çalışma ile de uyum göstermektedir. Söz konusu çalışmada akademisyenlerin pozitif psikolojik sermaye algılarının yüksek olduğu bulgusuna ulaşılmıştır. Benzer şekilde, Keser (2013) tarafından yapılan çalışmada, okul yöneticilerinin psikolojik sermaye düzey algılarının yüksek olduğu sonucuna ulaşılmıştır. Ocak, Güler ve Basım (2015) tarafindan Bosna'da öğretmenler ile yürütülen bir çalışmada, öğretmenlerin pozitif psikolojik sermaye algılarının öz yeterlilik, umut, iyimserlik ve psikolojik dayanıklılık alt boyutlarında yüksek düzeyde olduğu sonucuna ulaşılmıştır. Ancak alan yazın incelendiğinde, öğretmenlerin psikolojik sermaye algı düzeyinin orta seviyede olduğu sonucuna ulaşılan (Kaya, Balay ve Demirci 2014) bir araştırmanın da var olduğu görülmüştür.

Öğretmenlerin psikolojik sermaye kapasitelerinin yüksek olması performanslarını, öğretimdeki etkililiklerini, bağlılıklarını ve mesleki doyum düzeylerini olumlu etkilemektedir (Abbas ve Raja, 2010; Hajloo, 2013; Wang, Chen ve Hsu, 2014). Pozitif psikolojik sermayenin, iş görenlerin performans, iş tatmini, örgütsel bağlılık, stres düzeyleri ve iş devamlllı̆̆ üzerinde olumlu katkıları vardır (Luthans, Avolio, Avey ve Norman, 2007; Abbas ve Raja, 2010). Pozitif psikoloji insanların daha çok neyi yapabildiklerini belirlemesi açısından, kurumlar için göz ardı edilmemesi gereken bir kavramdır. Pozitif psikolojik sermaye seviyesi yüksek olan iş görenler, katkılarıyla çalıştıkları kurumları daha üst seviyelere taşıyacaklardır. Çalışanların sahip oldukları pozitif psikolojik sermayeleri tek başına yeterli olmasa da, oluşturacağı sinerji düşünüldüğünde oldukça önemli olduğu yadsınamaz (Tösten, 2015; Yalçın, 2019). Bu açıdan bakıldığında, eğitim iş görenleri olarak öğretmenlerin pozitif psikolojik sermaye düzeylerinin yüksek olması, pek çok anlamda eğitim programlarının ve eğitim kurumlarının amaçlarına olumlu katkılar sağlayacağı düşünülmektedir. Dolayısıyla, eğitim iş görenleri olarak öğretmenlerin yüksek düzeyde pozitif psikolojik sermaye düzeyleri, her bakımdan son derece olumlu bir durum olarak değerlendirilmektedir. Ancak bu tür algı çalışmalarının bir takım sınırlılıkları olduğunu da unutmamak gerekir. Buna göre, Aronson, Wilson ve Akert (2012), benzer durumları açıklamak için 'öz saygı' kavramından bahsederler. "Öz saygı; kendimiz hakkında iyi şeyler hissetme gereksinimi, insanların kendi özdeğerleri, yani kendilerini ne kadar iyi, yeterli ve saygın gördükleri ile ilgili değerlendirmeler" (Aronson, Wilson ve Akert 2012;s.53-54) olarak tanımlanmaktadır. Bu açıdan, çoğu insan öz saygısını olabildiğince yüksek tutmak, yani kendisini iyi, yeterli ve saygın biri olarak görmek ister. İnsanların dünyayı görme biçimlerinin altında, genellikle kendileri hakkında olumlu bir imgeye sahip olma gereksinimi olabilir (Aronson, Wilson ve Akert 2012). İngilizce öğretmenlerin sahip olduğu psikolojik sermaye algısının çok yüksek olduğu sonucunun bir nedeninin de 'özsaygı' kavramı olabileceği, başka bir ifadeyle, insanların kendilerini iyi, saygın ve yetkin biri olarak hissetme ihtiyacının etkisini akılda tutmak gerekmektedir.

Öğretmenlerin psikolojik sermayelerinin çok yüksek olarak belirlenmesinin bir başka nedeni de, yine sosyal psikolojinin konusu olan 'temel yükleme hatası' (fundamental attribution error) olarak değerlendirilebilir. Cüceloğlu (2015), yükleme süreçlerinin, kişinin kendisini ve çevresini anlama isteği sonucu kullanıldığını belirtir. Buna göre kişi kendisi ve başkalarıyla ilgili 
yüklemeler yaparken farklı davranır. Bu fark, kişinin kendi benlik bilincini destekleme ve koruma eğilimi yüzünden kendisini dıştan gözlemlemesinin olanaksızlığından kaynaklanır. Bu açıdan bakıldığında, öğretmenlerin pozitif psikolojik sermaye düzeylerini ortaya koyarken 'temel yükleme hatası' olasılı̆̆1 da göz ardı edilmemelidir. Nitekim Tösten (2015), yürüttüŭü çalışmada, öğretmenlerin pozitif psikolojik sermayelerinin yüksek olduğu sonucuna ulaşmıştır. Tösten ( 2015) benzer bir şekilde, bu tür araştırmalarda katılımcıların, yöneltilen yargılara anlam yüklerken ya da sorulara yanıt verirken, kendileri açısından ideal cevabı verme yatkınlığını ifade eden 'yükleme karmaşıklığı' kavramının söz konusu olabileceğinden bahseder. Dolayısıyla, yapılan çalışmalarda öğretmenlerin pozitif psikolojik sermaye düzeylerine yönelik algılarının yüksek seviyelerde bulunması, 'öz saygı' ve 'yükleme karmaşıklı̆̆g' gibi kavramların olası etkilerinin göz önünde tutulması gerektiğine işaret ediyor olabilir. Türkiye'de psikolojik sermaye üzerine yapılan çalışmaların sınırlı olması (Keleş, 2011), bu sınırlılığın eğitim yönetimi alanında çok daha fazla olması (Tösten ve Özgan, 2014), psikolojik sermaye üzerine yapılacak çalışmalara daha fazla yoğunlaşılması gerektiğini (Tösten, 2015) gösterir.

İngilizce öğretmenlerinin bu psikolojik sermayelerinin cinsiyet değişkeni açısından anlamlı bir farklılık göstermemesi, bir diğer ifade ile İngilizce öğretmenlerin sahip olduğu pozitif olan psikolojik sermaye algıları ile cinsiyet değişkeni arasında anlamlı olarak bir ilişki olmadığı sonucuna ulaşılması, alan yazındaki bazı çalışmalarla desteklenirken bazı çalışmalar ile farklılık göstermektedir. Örneğin, Kelekçi (2015), Büyükgöze ( 2014), Altınkurt, Ertürk ve Y1lmaz (2015), Tösten (2015), Kaya, Balay ve Demirci (2014), Barut (2017), Gökbulut ve Çoklar (2018) ve Yalçın (2019) tarafindan yapılan çalışmalarda, öğretmenlerin pozitif yönde psikolojik sermaye düzeyleri ile cinsiyet değişkeni açısından anlamlı olarak farklılık göstermediği sonucuna ulaşılmıştır. Bunlara ek olarak, Polatçı'nın (2011) psikolojik sermaye ile performans ilişkisinin incelediği araştırma ile Keser (2013) tarafindan gerçekleştirilen ve psikolojik sermaye ile otantik liderlik ilişkisinin incelendiği çalışmada cinsiyet değişkeni açısından anlamlı herhangi bir fark bulunmamıştır. Buna benzer şekilde Savur (2013) tarafından psikolojik sermaye ile otantik liderlik ilişkisinin incelendiği çalışmada, anlamlı bir fark bulunmamıştır. Yine Berberoğlu (2013) tarafindan psikolojik sermaye ile örgütsel vatandaşlık üzerine yapılan çalışma ile Çınar (2011) tarafından psikolojik sermaye ve örgütsel bağlılık ilişkisinin incelendiği çalışmada da, cinsiyet değişkeni açısından anlamlı bir fark bulgusuna ulaşılamamıştır. Ancak Yalçın (2019) tarafindan yürütülmüş olan çalışmada, öğretmenlerin cinsiyet değişkeni açısından, pozitif yönde psikolojik sermaye düzeyleri ile, 'öz yeterlilik' yönünden anlamlı bir farklılık olduğu sonucuna ulaşılmıştır. Çoban ve Demirtaş (2011), Erbaş (2018) ve Esen (2018) ise yaptıkları çalışmalar sonucunda, öğretmenlerin pozitif psikolojik algılarının cinsiyet değişkeni açısından anlamlı bir farlılık gösterdiğini belirlemişlerdir. Bu yönden, erkek öğretmenlerin öz yeterlilik alg1 düzeyleri, kadın öğretmenlerin öz yeterlilik algı düzeylerine göre daha yüksektir. Araştırmacılar bu farkın erkek öğretmenler lehine olmasının nedeninin, Türkiye toplumu gibi erkek egemen olarak kabul edilen toplumlarda daha dayanıklı ve mücadeleci olmak gibi özelliklerin, erkeklere atfedilmesinden kaynaklanmış olabileceğini belirtmişlerdir. Sonuç olarak bütün bu çalışmalara bakarak, cinsiyet değişkeni ile pozitif psikolojik sermaye arasında anlamlı bir ilişkinin varlığına veya yokluğuna dair kesin bir yargıdan söz etmek mümkün görünmemektedir. $\mathrm{Bu}$ durum, söz konusu alanda daha fazla çalışma yürütülmesi ihtiyaç duyulduğunu göstermektedir.

Araştırmanın bir başka alt problemi olan "Öğretmenlerin pozitif psikolojik sermaye düzeyleri, mesleki kıdemleri açısından anlamlı bir farklılık göstermekte midir?” sorusu ile alakalı bulgulara bakıldığında, anlamlı olarak bir fark bulunmadığı ortaya çıkmıştır. İngilizce öğretmenlerinin, beş yıllık dönemler şeklinde ele alınan çalışma yılları ile pozitif psikolojik sermaye düzeyleri arasında anlamlı bir fark bulunmadığı görülmüştür. Alan yazın incelendiğinde, elde edilen bu sonuçların Altınkurt, Ertürk ve Yılmaz (2015), Erbaş (2018) Gökbulut ve Çoklar(2018) ve Yalçın (2019) tarafından yapılan araştırma sonuçları ile benzerlik gösterdiği görülmüştür. Bu yapılan çalışmalarda da, çalışma yılı ile pozitif yönde psikolojik sermaye arasında 
anlamlı bir fark olmadığı sonucuna ulaşılmıştır. Buna karşın sonuçlar, Tösten (2015) tarafindan yürütülen çalışma sonuçlarıyla uyuşmamaktadır. Tösten (2015) tarafından Türkiye genelinde öğretmenler ile yapılan çalışmada, öğretmenlerin sahip olduğu pozitif yönde psikolojik sermaye düzeylerinin, mesleki kıdemlerine göre anlamlı bir şekilde farklılaştığı sonucuna ulaşılmıştır. Aynı şekilde, Berberoğlu (2013), Çimen (2013), Polatçı (2011) ve Barut (2017) tarafından yapılan çalışmalarda da bu yönde, yani çalışma süresinin artışı ile psikolojik sermaye düzeyinin de arttığı sonucuna ulaşılmıştır. Genç (2014) tarafından yürütülen bir başka çalışmada ise, kamu çalışanlarının psikolojik dayanıklılıklarının, kıdemlerine göre anlamlı derecede farklılaşmadığı sonucuna ulaşılmıştır. Keser (2013) tarafından eğitim yöneticileri ile yapılan psikolojik sermaye çalışmasında, mesleki kıdem yönünden anlamlı fark bulunmamış, ancak psikolojik dayanıklılık açısından fark olduğu sonucuna ulaşılmıştır. Bu farkın kaynağına dair gerçekleştirilen analizlerde, çalışma süresinin etkisinin olduğu belirlenmiştir. Ancak eldeki mevcut çalışmalara dayalı sonuçlara bakıldığında, öğretmenlik mesleğindeki tecrübe artışıla birlikte pozitif psikolojik sermaye algısının da artış gösterdiği yönünde kesin bir yargıya ulaşmak mümkün görünmemektedir.

İngilizce öğretmenlerinin mezun oldukları fakülte türü ile pozitif olan psikolojik sermaye anlayışları arasında anlamlı bir fark görülmemiştir. Bu açıdan araştırma sonuçları, Yalçın (2019) tarafından öğretmenlerin pozitif psikolojik sermaye düzeylerini belirlemek üzere yapılan çalışmayla örtüşmektedir. Ancak, ulaşılan bu sonuçlar Tösten (2015) tarafindan yürütülen çalışma sonuçları ile çelişmektedir. Tösten (2015), öğretmenler ile yaptığı çalışmada, öğretmenlerin pozitif psikolojik sermaye düzeyleri ile onların mezun oldukları fakülte çeşiti arasında anlamlı bir farlılık bulunduğu sonucuna ulaşmıştır. Buna göre fen edebiyat fakültesinden mezun öğretmenlerin psikolojik sermaye düzeyleri daha yüksektir. Diğer bir ifade ile eğitim fakültesi mezunu öğretmenlerin psikolojik sermaye düzeylerinin, diğer fakülte mezunlarına göre düşük olduğu gözlemlenmiştir. $\mathrm{Bu}$ sonuçlar ise, eğitim fakültelerinde öğrenim gören öğretmen adaylarına, teoriden daha fazla uygulama imkânı vererek, gerçek okul ve eğitim ortamlarını deneyimlemeleri sağlanabilmeli şeklinde değerlendirilmektedir.

$\mathrm{Bu}$ çalışmada, öğretmenlerin bu pozitif yönlü psikolojik sermaye algıları ile öğrencilerin yabancı dil dersi başarı puanları arasında anlamlı bir ilişki olmadığı sonucuna varılmıştır. Bir başka ifade ile söylemek gerekirse, İngilizce öğretmenlerinin sahip olduğu, olumlu özellikleri temsil eden pozitif psikolojik sermayelerinin, ortaokul 8. sınıf öğrencilerinin yabancı dil dersi sene sonu başarı notlarının anlamlı bir yordayıcısı olmadığı belirlenmiştir. Ulaşılan bu sonuçlar, alan yazında bazı çalışmaların sonuçları ile örtüşürken, bazıları ile örtüşmemektedir. Erbaş (2018), öğretmenlerin pozitif psikolojik sermaye düzeyleri ile öğrenen özerkliğini destekleme davranışlarına ilişkin görüşleri arasındaki ilişkiyi belirlemek üzere yürüttüğü çalışmada, öğretmenlerin pozitif psikolojik sermaye düzeylerinin toplam ölçek puanında 'çok yüksek' olduğunu saptamıştır. Öğrenen özerkliğini destekleme davranışlarına ilişkin hem toplam puanlarda hem de tüm alt boyutlar bazındaki puanların sonuçları, gereklilik düzeyinde 'her zaman' olarak belirlenmiştir. Bu sonuçlar, mutlak bir değerlendirmeyi mümkün kılmazken, bu alanda daha çok araştırma yapılmas1 gerekliliğine ihtiyaç duyulduğunu göstermektedir.

Kız öğrenciler ile erkek öğrencilerin yılsonu başarı notları karşılaştırıldığında, kız öğrencilerinin yabancı dil başarı notlarının anlamlı düzeyde farklı olduğu belirlenmiştir. $\mathrm{Bu}$ sonuçlar Bekirovic (2017) tarafından Bosna Hersek'te yapılan çalışma sonuçlarıyla örtüşmektedir. Söz konusu araştırma sonuçları Bekirovic (2017) tarafından kız öğrencilerin yabanı dil öğrenmeye yönelik daha yüksek motivasyona sahip olmalarına yorumlanmıştır. Zira, bu çalışmada da yabancı dile yönelik olumlu tutumun yabancı dil başarısının anlamlı düzeyde yordayıcısı olduğu sonucuna varılmıştır.

$\mathrm{Bu}$ araştırmada İngilizce öğretmenlerinin pozitif psikolojik sermaye alg1 düzeyleri ile ortaokul 8. sınıf öğrencilerinin İngilizce dersi başarıları arasında ilişki incelenmiştir. Araştırma sonunda, İngilizce öğretmenlerinin psikolojik sermaye düzeylerinin çok yüksek seviyede olduğu, 
ancak öğretmenlerin psikolojik sermayeleri ile öğrencilerin yabancı dil dersi başarı puanları arasında anlamlı görünen ilişki olmadığı saptanmıştır. Bir diğer ifade ile İngilizce öğretmenlerinin pozitif psikolojik sermayelerinin, ortaokul 8. sınıf öğrencilerinin İngilizce dersi başarılarının anlamlı bir yordayıcısı olmadığı sonucuna varılmıştır.

\section{Öneriler}

İngilizce öğretmenlerinin öğrencileriyle kuracağı olumlu ve yapıcı ilişkilerin, öğrencilerinin başarısı üzerinde etkili olabileceği göz önünde bulundurulduğunda, kalabalık sınıf ortamlarının buna engel olduğu düşünülürse, yabancı dil derslerinin doğasına uygun sınıf ortamları oluşturulmasının önemi açık bir şekilde görülebilir

Psikolojik sermaye ölçeğinin alt boyutlar bazında öğretmenlerin en az katılım gösterdikleri dışadönüklük ve psikolojik dayanıklılık alt boyutlar olması ve bu sonuçların başka çalışmalarda da son derece benzer olması göz önünde bulundurulduğunda, öğretmenlerin, eğitim öğretim sürecinin her aşamasında düşüncelerine başvurularak, kararlara ve uygulamalara en üst düzeyde katılımlarının sağlanması gereklidir.

Çalışma ortamlarında, özellikle eğitim kurumlarında pozitif bir iklimin katkısı açıktır. Bu açıdan bakıldığında, okul yöneticilerinin kurumlarında oluşturacakları pozitif iklim, eğitimin tüm paydaşlarına olumlu yansıyacağı, hatta öğrencilerin tutum ve kayg1 düzeylerine bile etki edebileceği unutulmamalıdır.

Bu çalışma Adana ilinde bulunan devlet ortaokullarında yürütülmüştür. Benzer çalışmalar, farklı illerde yürütülerek sonuçlar karşılaştırıla bilinir.

Devlet ortaokullarında yürütülen bu çalışmanın, özel okullarda da yapılarak sonuçlar karşılaştırılma yapılabilir.

\section{Kaynakça}

Abbas, M. ve Raja, U. (2010). Impact of psychological capital on innovative performance and job stress. Canadian Journal of Administrative Sciences, 32(2), 128-138. https://doi.org/10.1002/cjas.1314

Akman, Y. (2016). Öğretmenlerin psikolojik sermaye algılarının çeşitli değişkenlere göre incelenmesi. Dicle Üniversitesi Ziya Gökalp Eğitim Fakültesi Dergisi.28,268-277. http://dx.doi.org/10.14582/DUZGEF.729

Altınkurt, Y., Ertürk, A., ve Yılmaz, İ. (2015). Öğretmenlerin psikolojik sermayeleri ile tükenmişlik düzeyleri arasındaki ilişki. Journal of Teacher Education and Educators, 4(2) 166-187.

Arıkan, R. (2004). Araştırma Teknikleri ve Rapor Hazırlama. Asil Yayın Dağıtım

Aronson, E., Wilson, T., \& Akert, R. (2012). Social psychology.Pearson.

Barut, A. (2017). "Öğretmenlerin işyeri ruhsallı̆̆ ile pozitif psikolojik sermaye algıları arasındaki ilişkinin incelenmesi”, (Yanınlanmamış Yüksek Lisans Tezi, Gaziantep Üniversitesi).

Bećirović, S.(2017). The relationship between gender, motivation and achievement in learning English as a foreign language. European Journal of Contemporary Education 2017, 6(2) :210-220. https://doi.org 10.13187/ ejced.2017.2.210

Berberoğlu, N. (2013). Psikolojik sermayenin örgütsel vatandaşlık davranışı üzerine etkisi: bir alan araştırması (Yayımlanmamış Yüksek Lisans Tezi). Gazi Üniversitesi. 
Büyükgöze, H. (2014). Lise ögrretmenlerinin görüşlerine göre algilanan örgütsel destek ve psikolojik sermaye ilişkisi. (Yayınlanmamış Yüksek Lisans Tezi). Hacettepe Üniversitesi.

Büyükgöze, H., \& Kavak, Y. (2017). The relationship of perceived organizational support and psychological capital: An investigation among high school teachers. Educational Administration: Theory and Practice, 23(1), 1-32. https://doi.org/10.14527/kuey.2017.001

Chu, P. S., Saucier, D. A., \& Hafner, E. (2010). Meta-Analysis of the Relationships between Social Support and Well-Being in Children and Adolescents. Journal of Social \& Clinical Psychology, 29, 624-645. http://dx.doi.org/10.1521/jscp.2010.29.6.624

Cüceloğlu, D.(2015). Insan ve davranışı: Psikolojinin temel kavramları (31. Basım). Remzi Kitabevi

Çakmak, M. S., \& Arabacı, İ. B. (2017). Öğretmenlerin pozitif psikolojik sermaye algılarının iş doyumları ve örgütsel bağl1lıkları üzerindeki etkisi. Electronic Journal of Social Sciences, 16(62).

Çetin, F., Şeşen, H. ve Basım, H.N. (2013). Örgütsel psikolojik sermayenin tükenmişlik sürecine etkileri: Kamu sektöründe bir araştırma. Anadolu Üniversitesi Sosyal Bilimler Dergisi, 13 (3). 95-107.

Çetin, M., Özdemir, N. A. ve Akpolat, T. (2017). Okul yöneticilerinin psikolojik sermaye değerleri ve etik liderlik özellikleri arasındaki iliski. Uluslararası Eğitim Bilimleri Dergisi / The Journal of International Education Science. 4 (13), 247-267.

Çınar, E. (2011). Pozitif psikolojik sermaye’nin örgütsel bağlllıkla ilişkisi (Yayımlanmamış Yüksek Lisans Tezi). Dokuz Eylül Üniversitesi Sosyal Bilimler Enstitüsü.

Çoban, D. ve Demirtaş, H. (2011). Okulların akademik iyimserlik düzeyi ile öğretmenlerin örgütsel bağl1lığı arasındaki ilişki. Kuram ve Uygulamada Eğitim Yönetimi, 17(3), 317-348.

Duffy, J. R. (2013). Quality Caring: In Nursing and Health Systems (2nd Edition). Springer Publishing Company, LLC.

Envick, B. R. (2005). Beyond human and social capital: The importance of positive psychological capital for entrepreneurial success. The Entrepreneurial Executive, 10, 41-52

Erbaş, H., (2018). Öğretmenlerin pozitif psikolojik sermaye düzeyleri ile öğrenen özerkliğini destekleme davranışları (Yayınlanmamış yüksek lisans tezi). Bolu Abant İzzet Baysal Üniversitesi.

Erden, E. (1998). Öğretmenlik meleğine giriş. Alkım Yayınları

Eser, İ. (2018). Öğretmenlerin etik liderlik algısının işle bütünleşme ile olan ilişkisinde pozitif psikolojik sermayenin aracılık etkisi (Yayınlanmamış doktora tezi). Gaziantep Üniversitesi Eğitim Bilimleri Enstitüsü.

Furrer, C., \& Skinner, E. (2003). Sense of relatedness as a factor in children's acade-mic engagement and performance. Journal of Educational Psychology, 95, (1) 148-162. https://doi.org/10.1037/0022-0663.95.1.148

Gökbulut, B , Çoklar, A . (2018). Öğretmenlerin teknoloji kullanım düzeyleri ile psikolojik sermaye düzeyleri arasındaki ilişkinin belirlenmesi. Anadolu University Journal of Education Faculty, 2 (4), 280-294 http://dx.doi.org https://dergipark.org.tr/tr/pub/aujef/issue/41929/441691

Hajloo, N. (2013). Relationship between psitive psychological capacities and sense of humour among female teachers of Iran. Social and Behavioral Sciences, 84(2013 ) 93 - 96. 
Harms, P. D. ve Luthans, F. (2012). Measuring implicit psychological consructs inor-ganizational behavior: an example using psychological capital. Journal of Organizational Behavior, 33(4), 589-594.

İnanç, B. Y. ve Yerlikaya, E. E. (2015). Kişilik kuramları. Pegem Yayınları

Kalman, M. (2017). Ortaokul öğretmenlerinin psikolojik sermayelerinin geliştirilmesine yönelik bir uygulama. (Yayınlanmamış Doktora Tezi) (470232). Gaziantep Üniversitesi, Eğitim Bilimleri Enstitüsü.

Karasar, N. (2014). Bilimsel Araştırma Yöntemi. Ankara. Nobel akademi.

Kaya, A., Balay, R. ve Demirci, Z. (2014). Ortaöğretimde görev yapan öğretmenlerin psikolojik sermaye düzeylerinin incelenmesi (Şanlıurfa İli Örneği). Elektronik Sosyal Bilimler Dergisi, 13(48), 47-68.

Kelekçi, H. (2015). Öğretmenlerin pozitif psikolojik sermayeleri ile yeterlik inançları arasındaki ilişski. (Yayınlanmamış yüksek lisans tezi). Dumlupınar Üniversitesi Eğitim Bilimleri Enstitüsü.

Keleş, H. N. (2011). Pozitif psikolojik sermaye: tanımı, bileşenleri ve örgüt yönetimine etkileri. Organizasyon ve Yönetim Bilimleri Dergisi, 3(2), 343-330.

Keser, S. (2013). Illköğretim okulu yöneticilerinin otantik liderlik ve psikolojik sermaye özelliklerinin karşılaştırılması. (Yayımlanmamış Yüksek lisans Tezi). Yıldız Teknik Üniversitesi Sosyal Bilimler Enstitüsü.

Lomas, T., \& Ivtzan, I. (2015). Second wave positive psychology: Exploring the positive-negative dialectics of wellbeing. Journal of Happiness Studies, 7,1,753-1,768.

Luthans F, Youssef CM, Avolio BJ. (2007). Psychological capital. Oxford University Press

Luthans, F. ve Youssef, C. M. (2004). Human, social, and now positive psychological capital manage $\neg$ ment: investing in people forcompetitive advantage. Organizational Dynamics 33(2). 143-160.

Luthans, F. ve Youssef, C. M. (2007), Emerging positive Organizational Behavior, Journal of Management, 33(3), 321-349.

Luthans, F., Avolio, B. J., Avey, J. B., \& Norman, S. M. (2007). Positive psychological capital: measurement and relationship with performance and satisfaction part of the management sciences and quantitative methods commons. Personnel Psychology, 60, 541-572. https://doi.org/10.1111/j.1744-6570.2007.00083.x 